\title{
Landmark Food and the Construction of Food Tourism City of Chongqing
}

\author{
Ma Jianlin \\ Chongqing Business Vocational College, Chongqing 4001331
}

Keywords: Landmark food; food Tourism; city construction

Abstract. The concept and formation of landmark food has been recognized by most people. Among the six elements of tourism, food is indispensable for people's life, and is also dominated in tourism income. Combining the development of landmark food and local tourism in Chongqing, this paper put forward the importance of developing food Tourism in Chongqing, and proposed to develop food tourism according to the regional differentiation, create landmark food stores and special food street to build a city for food Tourism and enhances the image of city tourism.

\section{Introduction}

Tourism has become an indispensable part of people's life. It the era of mass tourism, people travel frequently and have accumulated a wealth of experience. Meanwhile, the demand for tourism has gradually become personalized and diverse. How people interpret tourism changes greatly. Travelers are no longer satisfied with the traditional way of tourism, that is, get a hurried and cursory glance at the scenery, but prefer to obtain spiritual and cultural satisfaction through tourism. Tourism motives are gradually diversified. And food Tourism which aims at enjoyment and experience has gradually become the mainstream of tourism. In 2017, according to the sample survey statistics, the average overnight spending of domestic tourists reached 1369.84 Yuan per capita. In terms of cost allocation, food and beverage accounted for $17.82 \%$, accommodation accounted for $24.30 \%$, shopping accounted for $14.43 \%$, and transportation accounted for $14.00 \%{ }^{1}$. In the tourism consumption structure, the proportion of "food" is large. At the same time, according to the "2018 China Restaurant Industry Survey Report” issued by the China Hospitality Association, Chongqing's catering revenue in 2017 was 115.31 billion Yuan, up $12.1 \%$ from a year ago, ranking 12th in the country. The income of catering industry plays an important role in the development of the local economy.

\section{Landmark Food and Food Tourism}

\subsection{Landmark food}

It was not until the "Chinese Landmark Food Tour Tasting” hosted by the Yunnan Provincial Catering and Chinese Food Association in November 2014 that the landmark food was proposed in China ${ }^{2}$. Chinese scholar Shi Zibin published the article "On the Application and Function of Landmark Food" on "Jiangsu Condiment and Subsidiary Food", which defines the concept of the landmark food. He believes that the landmark food is the local original dishes with cultural historical significance, tested by the market. The raw materials, spices and cooking methods must have local characteristics, and produce local flavors, reflecting the local food culture connotation. In a word, landmark food must be able to represent regional characteristics. China has vast territory and abundant resources. Different regions have their own unique eating habits due to different climate, ethnicity and customs. This has laid the foundation for the formation and development of food tourism.

\subsection{Food tourism}

Regarding food Tourism, the domestic research started late, and the number was small. It was not until the late 1990s that the concept of food Tourism was proposed. Moreover, the author searched for food Tourism in CNKI (China National Knowledge Infrastructure), and there were only about 150 results related to it. However, the representative Chinese scholar Weng Yi proposed in his master's thesis that

\footnotetext{
${ }^{1}$ Xinhuanet. Statistical Communique of the 2017 National Economic and Social Development of Chongqing [OL].http://www.cq.xinhua- 2018 ${ }^{2}$ Li Jialin. 12 "Landmark" Dishes Recommended by Yunnan F-B\&Delicacy Trade Association [N].Yunnan Information News, 2014-11-18(D10).
} 
the food Tourism refers to the seeking aesthetic and pleasure in different places, and that it is a tourism activities with social and leisure nature, mainly to enjoy and taste the food ${ }^{3}$. In the tourism consumption, the proportion of expenditure on eating is relatively high. This has prompted major tourism cities to focus on building tourism and shaping the image of the city while attach great importance to the creation of food and the food brands. Integrate tourism and food to enhance the city's popularity and reputation.

\section{The Necessity of Developing Food Tourism in Chongqing}

Located at the middle and lower reaches of the Yangtze River, Chongqing is an important pivot for the development of the western region of the country. Chongqing is also a historical and cultural city with the Bayu culture, the auxiliary capital culture, and the anti-Japanese culture. Chongqing City is built by the mountain, surrounded by two rivers, and rich in products. It has fostered generations of intelligent people. The great history has bestowed Chongqing the unique dietary habit and rich food tourism resources. Chongqing cuisine has attracted more and more attention with the establishment of Chongqing municipality and economic development. Chongqing people are constantly looking for human symbols of their own unique charm, and Chongqing cuisine is a city card with a long history and rich content. Since 2006 when the Chongqing Municipal Government issued the "Opinions on Accelerating the Development of the Catering Industry and Promoting the Construction of the Food Capital", the construction of the gourmet city has officially been launched and has made considerable progress. In 2009, the State Council issued the "Opinions on Promoting Chongqing's Urban and Rural Reform and Development” which clearly propose to build Chongqing as a gourmet city in the upper reaches of the Yangtze River and make the construction as a national strategy. In 2012, Chongqing government introduced the "Implementation Opinions on Promoting the Construction of Food City", proposing the plan to build the gourmet city of the upper reaches of the Yangtze River in 2017 and the city of Chinese cuisine in 2020. Chongqing's unique geographical advantages, rich tourism resources, and profound food culture, coupled with the guidance and support of government policies, have provided favorable conditions for Chongqing to develop gourmet tourism.

\section{Ways to Build a Gourmet Tourism City}

As for tourism, Chongqing intends to build itself a world famous tourist city. With regard to the strategic positioning of food, it aims to become a gourmet city. In the "13th Five-Year Plan" for the construction of an internationally renowned tourist destination in Chongqing, it is proposed to create a gourmet destination to give play to the brand advantage of "eating in Chongqing" and promote the food culture of Bayu. Therefore, it is necessary to make reasonable planning for food tourism in Chongqing, build on details, deliver culture, produce brands and make fine products.

\subsection{Develop gourmet tourism by regional differentiation in line with Chongqing tourism development plan}

Simply put, Food tourism organically combined food and tourism. Chongqing tourism has entered a stage of rapid development. With the implementation of the "Belt and Road" initiative and the construction of the Yangtze River Economic Belt, the further development of the western region, tourism will become a comprehensive strategic pillar industry in Chongqing. It is also a booster for stimulating domestic demand, targeted poverty alleviation, and the construction of "landscape capital beautiful Chongqing". According to the " $13^{\text {th }}$ five year plan" outlines to construct Chongqing as an internationally renowned tourist destination issued by Chongqing Municipal Government in 2016, the project contains three International tourist destinations, namely “Geocity, Dasanxia, Dawuling”, and Chongqing scenery route centering on the Yuzhong Peninsula, Chongqing northeast route around Yangtze River Three Gorges, and southeast Chongqing route with the ethnic customs. In this respect, the food tourism can be planned from a macro perspective according to Chongqing tourism development. In the light of

\footnotetext{
${ }^{3}$ Weng Yi. On the Development of Food Tourism in Fujian Province [J].Fujian Normal University (Master Thesis), 2004.
} 
highlighting local characteristics and differentiated development, it can rationally lay out and create the cuisine of each region according to the local food tourism resources of different routes.

\subsection{Create a landmark food and beverage restaurant}

Chongqing's rich food resources have prompted a large number of gourmet enterprises many of which have enjoyed a high reputation in the country. With the changes in history and the rapid development of catering enterprises in recent years, Chongqing has now formed a number of China Time-honored Brand, hot pot, Chinese food. Old Sichuan Restaurant and Xiaodongtian Restaurant are China Time-honored Brands. There are also famous Chongqing hot pot enterprises, such as Dezhuang, Kong Liang hot pot, Qin Ma hot pot, etc., and Chinese food representative Tao Ranju, A Xing Ji, Shun Feng 123, etc. These companies are committed to characteristics shaping according to the type of business. As landmark food, they are iconic. Therefore, these representative companies are required to highlight their uniqueness in terms of decoration, dishes, utensils, and employee uniforms.

\subsection{Create distinct food street}

Among the food streets, "Haochi Street" in the Jiefangbei business district is familiar to tourists. However, there are other popular spots in Chongqing like the Nanshan hot pot street and the Longtou Temple hot pot street. In particular, tourists in the Nanchang old factory hot pot street can not only enjoy the beautiful night view, but also enjoy a spicy and mellow hot pot when night falls. So locals and tourists prefer to it. For tourists, they are very eager to go where local people eat local cuisine, and in these areas, they can taste Chongqing sweet potato hot pot, Dalong old hot pot, Yuzong old stove hot pot and so on. The hot pots have their own specialties and different flavors.

"Gourmet" is a visit card of Chongqing. Food Street is the most important food resources, and also the display window to present the food ingredients, business entities, tastes, food culture and so on. The food and beverage industry attaches great importance to the Food Street, and combines various tourism resources to create special food streets that integrate leisure, entertainment, tourism and other forms of business. For example, Chongqing's southeast district is the major settlement of ethnic minorities. The national costumes and diet are full of local national characteristics. In the creation of Food Street, it is possible to integrate local ethnic characteristics. In this way, visitors can taste traditional ethnic cuisine in the Food Street, and watch various folk performances such as Xiushan Lantern and Stone Pillars Waving Dance, etc. This paper classified and organized the current Food Street in Chongqing.

Table 1 Chongqing food street distribution and representative food

\begin{tabular}{|c|c|c|}
\hline Regions & Food Street & Food or specialty \\
\hline \multirow{3}{*}{$\begin{array}{l}\text { Main districts of } \\
\text { Chongqing }\end{array}$} & Haochi Street & $\begin{array}{l}\text { Pangzimachuanchuan, Haoyoulai hot and sour rice } \\
\text { noodles, Small dumplings }\end{array}$ \\
\hline & Keyuan Food Street & $\begin{array}{l}\text { Sichuan cuisine, Guangdong cuisine, Seafood, Hot pot, } \\
\text { Soup pot }\end{array}$ \\
\hline & $\begin{array}{l}\text { Nanbin Road Food Street } \\
\text { Ciqikou Folk custom Food Street }\end{array}$ & $\begin{array}{l}\text { Hot pot, Sichuan cuisine, Guangdong cuisine } \\
\text { Hot and Sour Rice Noodles, Duck blood cake, Chen twist, } \\
\text { Chuanchuan }\end{array}$ \\
\hline \multirow{3}{*}{ New urban district } & $\begin{array}{l}\text { Rongchangchangzhou Food } \\
\text { Street }\end{array}$ & Leaf wrapped rice, Yellow bean jelly, Spiced white goose \\
\hline & PeilingBinjiang road Food Street & Wujiang fish, FulingZhacai \\
\hline & $\begin{array}{l}\text { JiangjinBinjiang food and culture } \\
\text { street }\end{array}$ & Hot peppers chicken, Fish in sour soup \\
\hline \multirow{2}{*}{ Northeast Chongqing } & $\begin{array}{l}\text { Xishan food street } \\
\text { Mantan road grilled fish street }\end{array}$ & $\begin{array}{l}\text { Grilled fish, Pea meal } \\
\text { Grilled fish }\end{array}$ \\
\hline & $\begin{array}{llll}\text { Xiushan } & \text { flower lantern Food } \\
\text { Street }\end{array}$ & Xiushan preserved beancurd, Xiushan rice tofu \\
\hline \multirow{3}{*}{ Southeast Chongqing } & $\begin{array}{llll}\begin{array}{l}\text { Binjiang } \\
\text { market }\end{array} & \text { golden bank night } \\
\end{array}$ & Barbecue, Potato tuber rice, Preserved meat \\
\hline & Binjiang road Food Street & Fresh fish hot pot, Dry pot \\
\hline & Fairy Food Street & Wild boar meat, Soup pots, Roast potatoes \\
\hline
\end{tabular}




\subsection{Build food museums}

At present, the Gourmet Museums that we can find on the internet are the top ten worldwide food museums such as the Seoul Kimchi Museum in Korea, the Yorkshire Chocolate Museum in the UK, and the Udon Museum in Kyoto, Japan. The earliest food museum in China was the China Food Culture Museum, which was established in 2002. It is also the world's first thematic museum to study food culture. According to Zhou Hongcheng's "Comparative Study on the Status Quo of the Construction of Chinese and Foreign Food Culture Museums” published in “China Condiment” in March 2018, according to incomplete statistics. These museums mainly feature in local famous dishes, condiments, specialty foods and tea, wine and beverages. Chongqing has fewer food museums than other cities. Therefore, in addition to pickle museum and hot pot museum, we should create a new type of interactive and experiential museums through the development of tourism and regional characteristics. These museums can be food museums integrating tour, food production, and product sales.

\subsection{Hold influential food festivals}

With the support and cooperation of the municipal government, the municipal commercial committee, and industry associations, Chongqing holds annual food festivals, and some of them have a certain scale and influence. At present, the main food festivals in Chongqing are mainly based on food. In particular, the hot pot festival held in recent years not only allows consumers to experience the joy of eating, but also enhances the cultural connotation of hot pot and better inherits the hot pot culture by organizing Chinese hot pot industry summit and Chongqing hot pot culture corridor and other activities during festival. The author invested and conducted statistics on some food festivals in Chongqing. The China (Chongqing) Hot Pot Food Culture Festival and the Chongqing International Food Festival belong to the municipal level. Others belong to the district and county level. Apart from the main districts in city, other districts and counties will hold various food festivals, and several districts and counties in the southeastern part of the country will even hold a food festival jointly every year. This demonstrates that all levels of departments attach great importance to the food festival. The food festival should not only pay attention to the form, but also have connotation. This will be an important way to expand local influence and enhance the image of the city.

Table 2 Name and location of each food festival

\begin{tabular}{|c|l|l|}
\hline Regions & \multicolumn{1}{|c|}{ Name of the festival } & \multicolumn{1}{|c|}{ Host place } \\
\hline \multirow{5}{*}{$\begin{array}{c}\text { Main districts of } \\
\text { Chongqing }\end{array}$} & $\begin{array}{l}\text { China (Chongqing) hotpot cuisine and } \\
\text { culture festival }\end{array}$ & $\begin{array}{l}\text { CQ International Convention } \\
\text { \& Exhibition Center }\end{array}$ \\
\cline { 2 - 3 } & Chongqing international food festival & $\begin{array}{l}\text { CQ International Convention } \\
\text { \& Exhibition Center }\end{array}$ \\
\cline { 2 - 3 } & $\begin{array}{l}\text { Chongqing famous snack food culture } \\
\text { festival }\end{array}$ & $\begin{array}{l}\text { CQ International Convention } \\
\text { \& Exhibition Center }\end{array}$ \\
\cline { 2 - 3 } & $\begin{array}{l}\text { Chongqing nanshan spring chicken } \\
\text { culture festival }\end{array}$ & Nanshan district \\
\cline { 2 - 3 } & $\begin{array}{l}\text { Chongqing chef festival and chongqing } \\
\text { cuisine outdoor food festival }\end{array}$ & Jiulongpo district \\
\hline \multirow{5}{*}{$\begin{array}{c}\text { Districts and } \\
\text { counties }\end{array}$} & Jiangjininternational food festival & Jiangjin district \\
\cline { 2 - 3 } & $\begin{array}{l}\text { Chongqing zhongzhou famous snack } \\
\text { food festival }\end{array}$ & Zhongxian county \\
\cline { 2 - 3 } & Rongchang spiced goose food festival & Rongchang district \\
\cline { 2 - 3 } & Hechuan international food festival & Hechuan district \\
\cline { 2 - 3 } & Youyangtaohuayuan food festival & YouYang county \\
\hline
\end{tabular}

\subsection{Build business catering centers}

Chongqing's local economy has developed rapidly. In addition to the existing business districts such as the Yuzhong Peninsula, Shapingba District and Guanyin Bridge, Liangjiang New Area, Yubei District and the one-hour economic circle have gained great momentum in development, and there are centralized business districts in these regions which must-see shopping resorts for local residents and tourists. Based on that, we can create a business catering center with a variety of foods and a concentrated consumption 
in the business district, such as the Tianjie project built by local Longhu Real Estate in various regions. At present, there are Times Tianjie, BeichengTianjie, XichengTianjie, and UchengTianjie where business catering has been formed, and local brands and exotic catering brands have been introduced. There are also different levels of consumption to meet the needs of different groups of people, thereby increasing the popularity of the business circle, promoting people's consumption and stimulating the local economy.

\section{Conclusion}

The development of tourism is inseparable from food. From the perspective of tourists, as long as them get to a city, they are eager to taste local specialties to understand local history, local culture and local customs. From the perspective of tourism development, diet accounts for a high proportion of tourism income. Therefore, we can capitalize on the food to drive the development of local tourism. Food tourism not only satisfies people's diet demands, but also generates profits, and further enhances the city's popularity and reputation.

\section{Acknowledgement}

Fund project: This paper is one of the phased results of the Sichuan Food Development Research Center project "On Chongqing Image Building by Gourmet Tourism" of the Humanities and Social Sciences Key Research Base of the Sichuan Provincial Department of Education. Project number: CC18G10.

Fund project: Project of Chongqing Municipal Education Commission Humanities and Social Sciences which is called Sustainable Developmental research of 'Yangtze Economic Belt' in National Strategic Background of Food Capital- Chongqing (17SKG293).

This paper is one of the achievements of the "Internet +" Tourism Collaborative Innovation Center of Chongqing Business Vocational College

\section{References}

[1] Li Jialin. 12 “Landmark” Dishes Recommended by Yunnan F-B \& Delicacy Trade Association [N].Yunnan Information News, 2014-11-18(D10).

[2] Weng Yi. On the Development of Food Tourism in Fujian Province [J].Fujian Normal University(Master Thesis), 2004.

[3] Shi Zibin. On the Application and Function of Landmark Food [J].Jiangsu Condiment and Subsidiary Food, No. 1 of 2018

[4] xinhuanet. Wait for Cultural Breakthrough to Build a Gourmet City, Chongqing [EB]. http://news.xinhuane- 2015

[5] xinhuanet. Statistical Communique of the 2017 National Economic and Social Development of Chongqing [OL].http://www.cq.xinhua- 2018 